\title{
STRUCTURAL BEHAVIOR OF PRESTRESSED CONCRETE BRIDGE GIRDER WITH EPOXY JOINT
}

Assylkhan Jalairov ${ }^{1}$, Dauren Kumar ${ }^{2, *}$, Khaini-Kamal Kassymkanova ${ }^{3}$, Zeynep Sarsembekova ${ }^{2}$, Gulzhan Nuruldaeva ${ }^{4}$, Gulnar Jangulova ${ }^{2}$

${ }^{1}$ Department of Transport, Construction, Bridges and Tunnels, Kazakh University of Way Transport, Almaty, Republic of Kazakhstan

${ }^{2}$ Department of Cartography and Geoinformatics, Al-Farabi Kazakh National University, Almaty, Republic of Kazakhstan

${ }^{3}$ Satbayev University, Almaty, Republic of Kazakhstan

${ }^{4}$ Institute of Architecture and Construction, Satbayev University, Almaty, Republic of Kazakhstan

*E-mail of corresponding author: daurendkb@gmail.com

\section{Resume}

The study object is a prototype of a composite bridge prestressed concrete beam with a length of $42.0 \mathrm{~m}$ for road bridge desks for perception of impact from motor vehicles in the form of A14, NK-120 and NK-180 loads.

The experimental deflection of the beam in the midspan had a value equal to $f_{\text {exp }}=62.4 \mathrm{~mm}$ at a load of $2 \mathrm{P}_{\mathrm{K}}=436 \mathrm{kN}$, which was $75.2 \%$ of the control deflection value.

Based on the test results, the girder block joints with "tooth" and "notch" device are found to be imperfect.

The experimental load of $2 \mathrm{P}_{\mathrm{MAX}}=822.7 \mathrm{kN}$ was achieved during the tests, which exceeded the control load equal to $2 \mathrm{P}_{\mathrm{k}}=744 \mathrm{kN}$ when checking the strength of the composite beam and the control load equal to $2 \mathrm{P}_{\mathrm{K}}=790 \mathrm{kN}$ when checking the strength of No. 1 and No. 2 joints.

Available online: https://doi.org/10.26552/com.C.2022.2.D59-D71

\section{Article info}

Received 4 August 2021

Accepted 6 October 2021

Online 26 January 2022

\section{Keywords:}

composite bridge beam

outer or end segment

middle segment

tests

stiffness

crack resistance

strength

ISSN 1335-4205 (print version)

ISSN 2585-7878 (online version)

\section{Introduction}

The prototype of a composite beam consists of three segments - two outer and one middle (Figures 1, 2, 3). The length of the outer blocks is $14000 \mathrm{~mm}$ each. The middle segment has the shape of inverted trapezoid - the block has a length of $14010 \mathrm{~mm}$ at the top and $14000 \mathrm{~mm}$ at the bottom.

The composite beam blocks have a T-section with a widened part at the bottom in the transverse profile to place prestressing tendons.

The concrete strength class of the beam blocks is adopted B40 in accordance with the project.

Tendons consists of K-7 seven wire strands with a diameter of $15 \mathrm{~mm}$ from Beloretsk Metallurgical Plant, with increased physical and mechanical characteristics in comparison with the characteristics given in the normative document [1]. Technical requirements, have been adopted as prestressed reinforcement. Six tendons have been adopted when reinforcing the composite beam with prestressing tendons, where each tendon consists of seven K-7 strands. The controlled force due to prestressing was assumed to be equal to $1292 \mathrm{kN}$ in accordance with the project.
Figures 4 and 5 show respectively No. 1 and No. 2 joint zones for joining the middle segment with two end segments. There is a shear key with a "tooth" and a "cutout" for the formation of a dowel in the middle part of the depth of these segments. Cutouts in the blocks edge to form monolithic reinforced concrete dowels are shown in Figures 4 and 5. The concrete strength class of dowels was adopted as equal to B30 according to the project [2].

Before joining, the composite beam segments have been installed on a specially made conductor - slipway and K-7 strands have been pulled through the ducts. Figure 6 shows a general view on the end face of the end segments with K-7 strands laid in channel formers.

\section{Materials and methods}

Testing of the bridge girder was conducted at the Almaty Bridge Structures Plant (hereinafter AZMK).

The composite beam blocks have been joined to each other in the conductor-slipway by tensioning of prestressing tendons. Layers of BASF (Concresive 1420) epoxy based two-component adhesive have been applied 


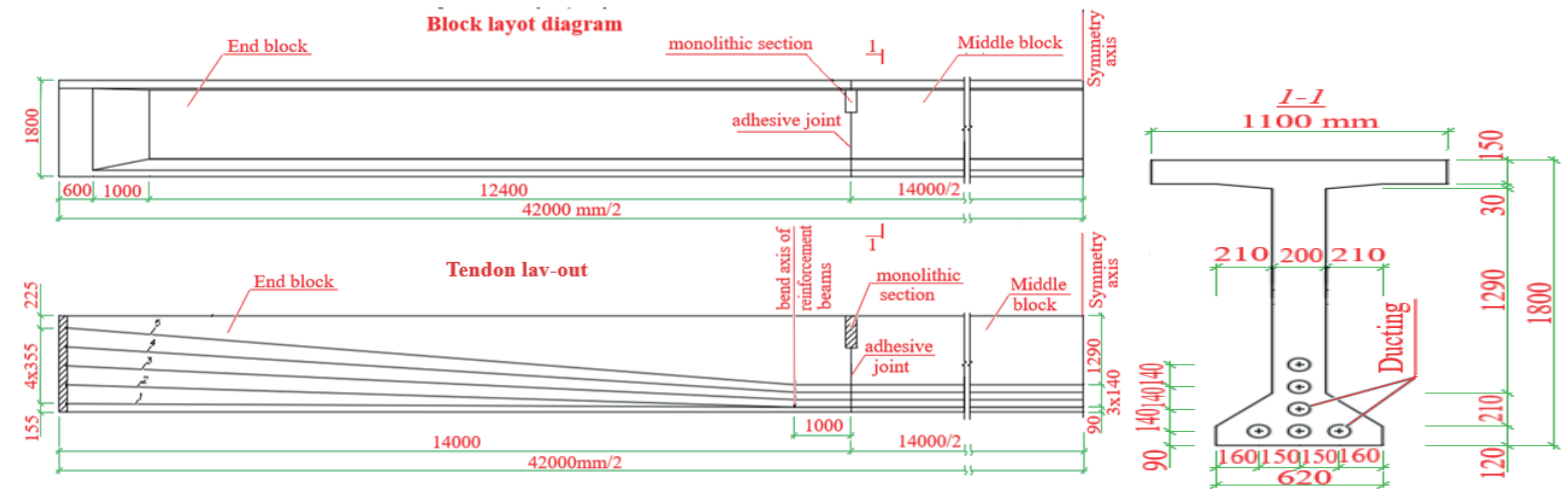

Figure 1 General data, segment layout scheme and the position of prestressing tendons
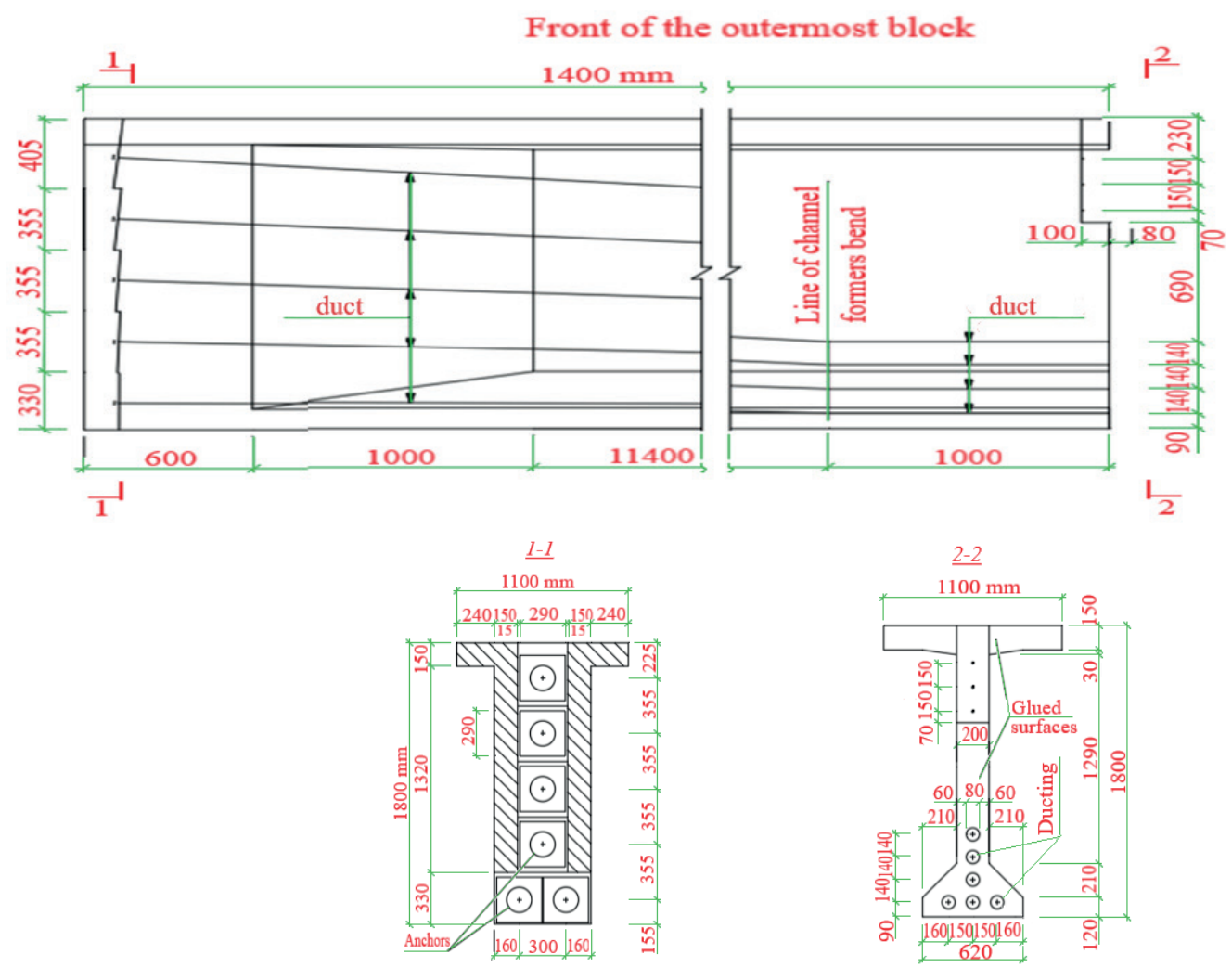

Figure 2 Dimensions of the girder and initial data of the outer segment

$1100 \mathrm{~mm}$

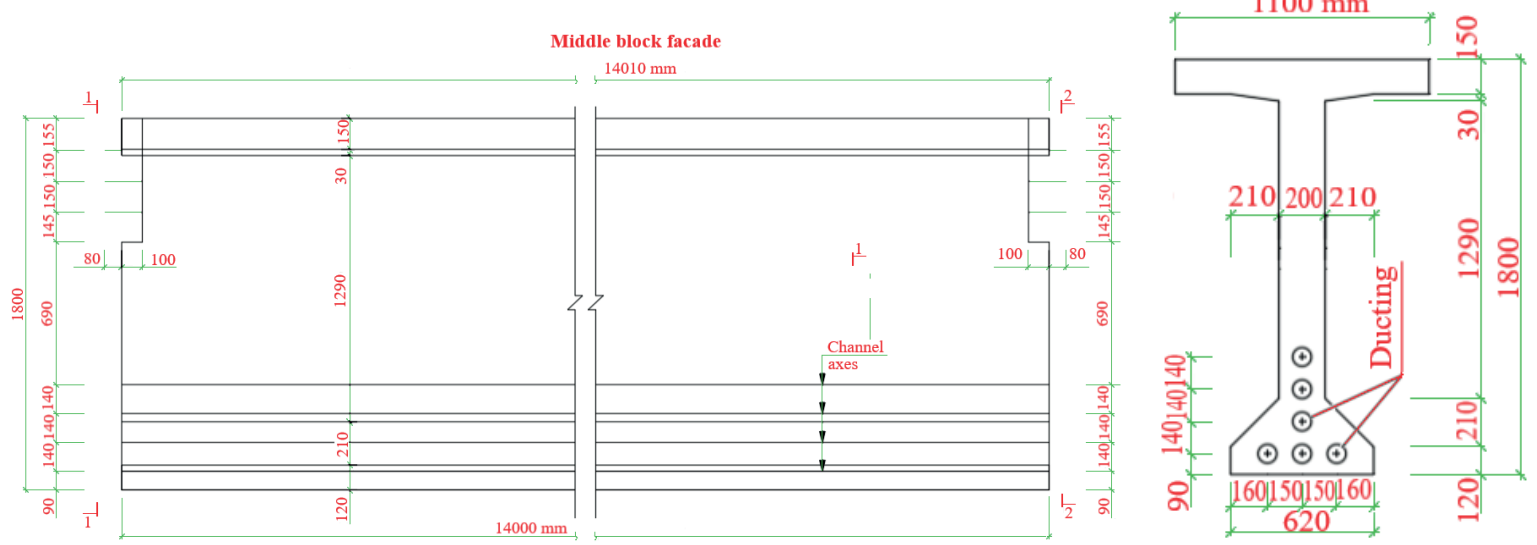

Figure 3 Dimensions of the girder and initial data of the middle segment 


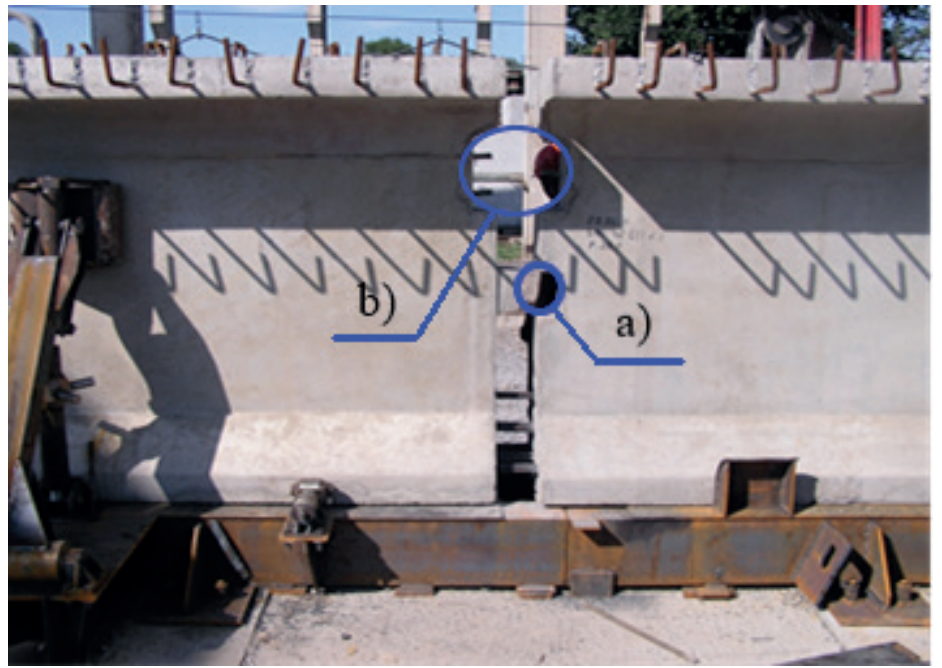

Figure 4 No. 1 adhesive joint zone (the end segment on the left in the picture): a) there is a "tooth" and a "cutout" for the formation of a dowel in the middle part of the height of blocks; $b$ )"cutouts" are placed in the upper zone of the blocks edges, to form a monolithic dowel

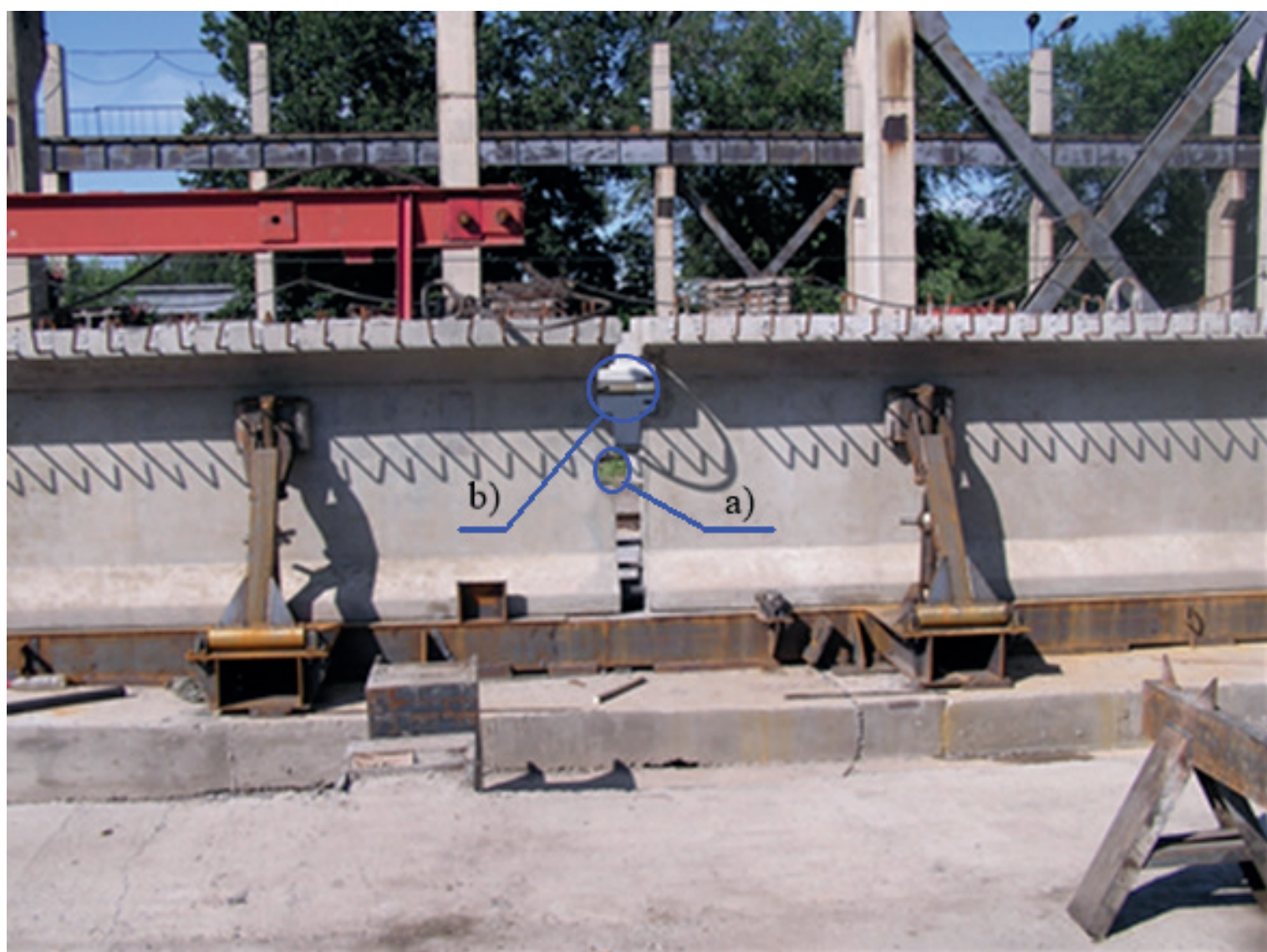

Figure 5 No. 2 adhesive joint zone (the middle segment on the left in the picture): there is a "tooth" and a "cutout" for the formation of a dowel in the middle part of the height of segments, b)"cutouts" are placed in the upper zone of the segment edges, to form a monolithic dowel 


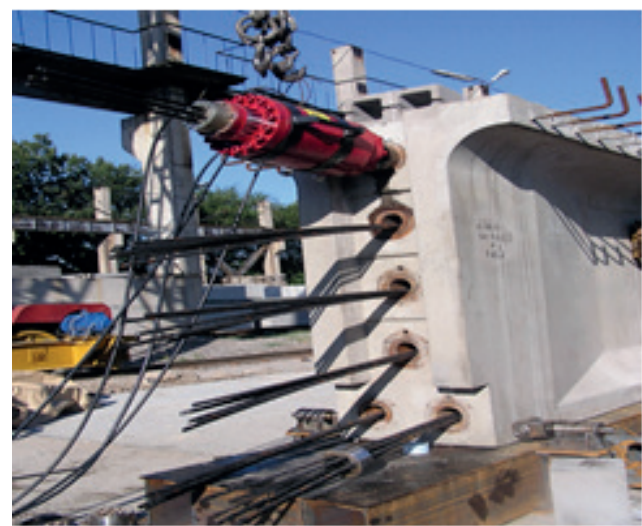

Figure 6 General view of the end face of the outer segments with K-7 strands laid in channel formers, a hydraulic jack is installed at the top for tensioning the upper due to prestressing tendons

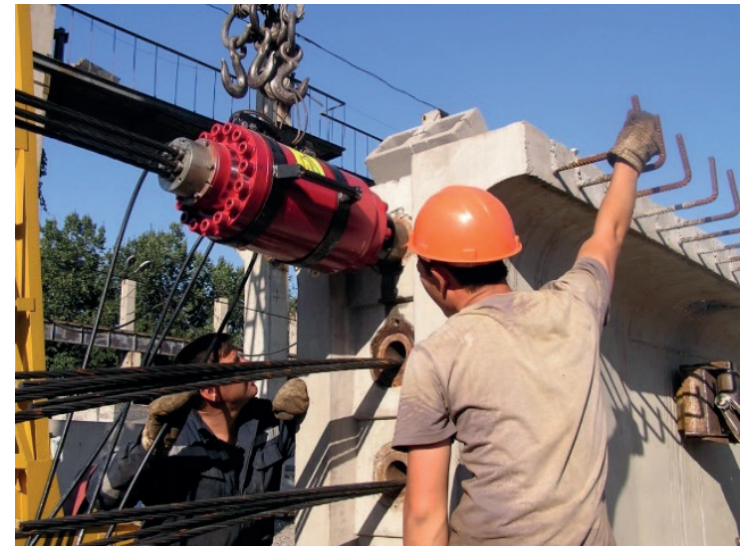

Figure 7 Tension of the upper tendon made of $K-7 \emptyset 15$ strands

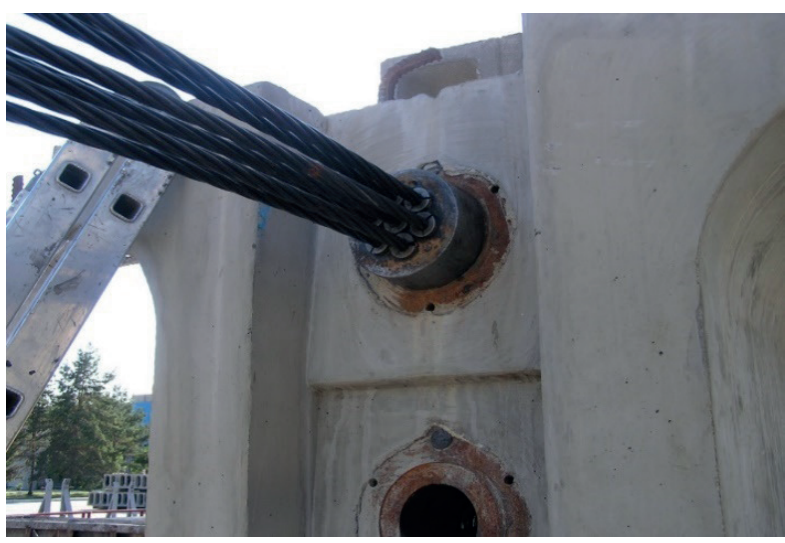

Figure $8 \mathrm{~K}-7 \varnothing 15$ anchored strands of the upper tendon

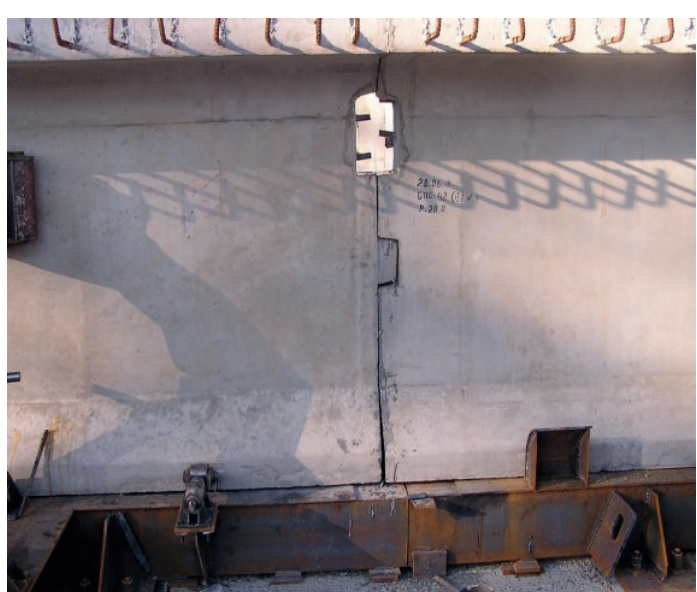

Figure 9 Missing contact of the segment heads of 42.0-mlong composite beam in No. 1 adhesive joint zone after the tension of the prestressing tendons

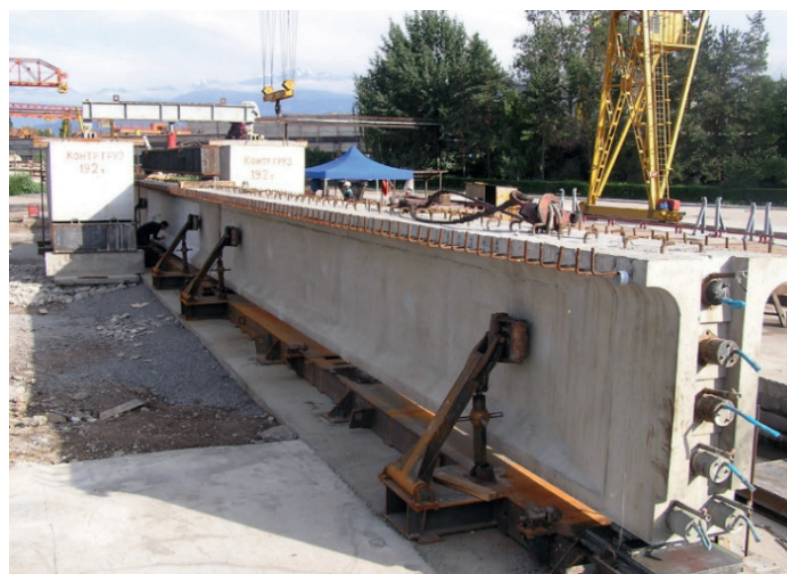

Figure 10 The fittings designed for injecting grout are shown at the end of the composite beam

to the joint surfaces of the blocks (No. 1 and No. 2 joints) before tensioning of the bundles of prestressed reinforcement [3-9].

The upper tendon has been tensioned using DN-7 hydraulic jack after applying the adhesive to the joint surfaces of the blocks (Figures 7 and 8). Then the second bundle has been tensioned when counting from the top to bottom according to the sequence adopted in the project.
The remaining four tendons have been further tensioned for the next day after the adhesive has been cured and the tension sequence was observed the same - the third tendon was tensioned first when counting from the top to bottom. The last tendons of the lower row of the prestressed reinforcement have been tensioned. Seven K-7 strands that are part of one tendon have been anchored after the tensioning of each prestressing tendons. (Figure 8). 

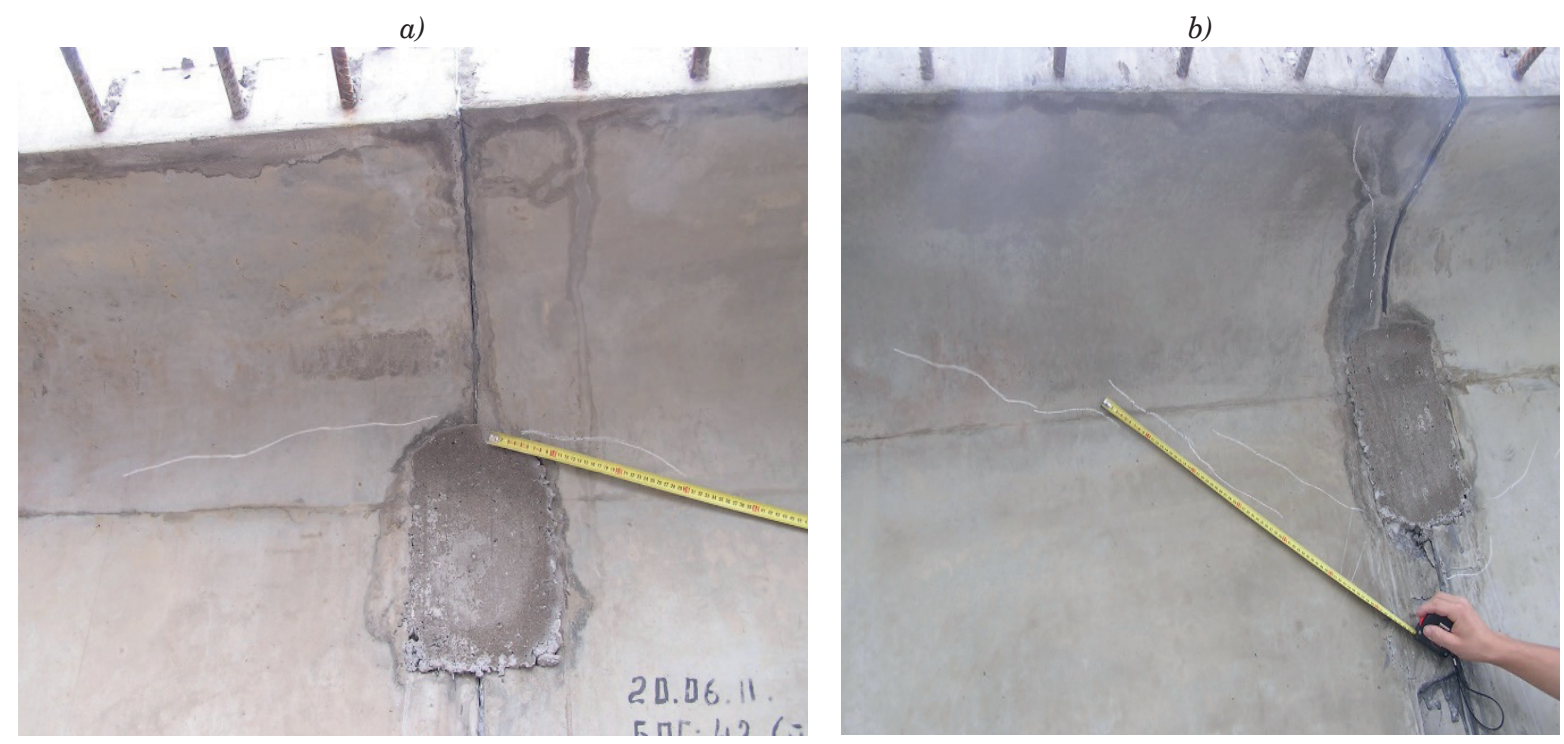

Figure 11 Cracks formation in blocks concrete in the monolithic insert zone after stressing of 42.0-m-long composite beam by tendons: the southern side of No. 1 adhesive joint; b) the northern side of No. 1 adhesive joint

a)

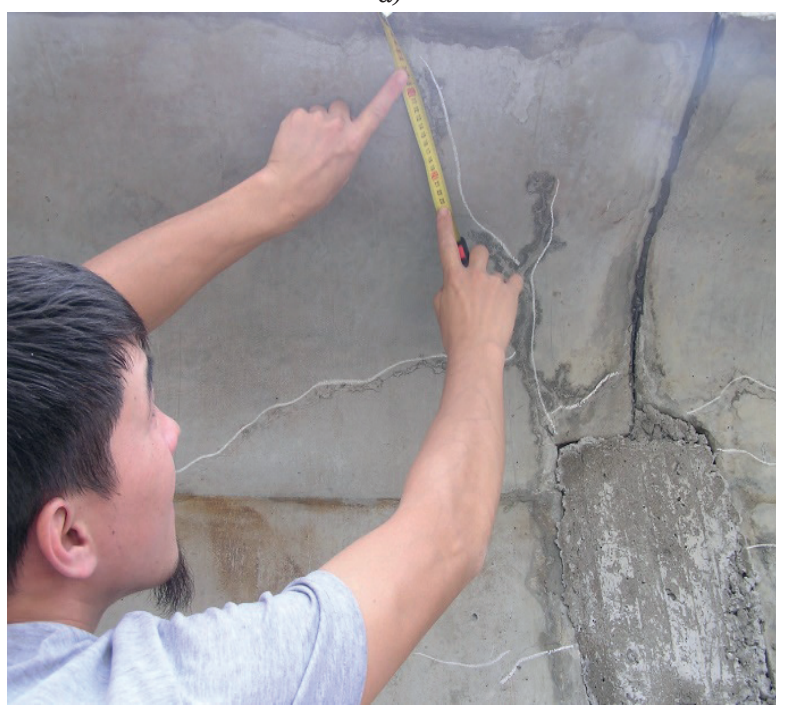

b)

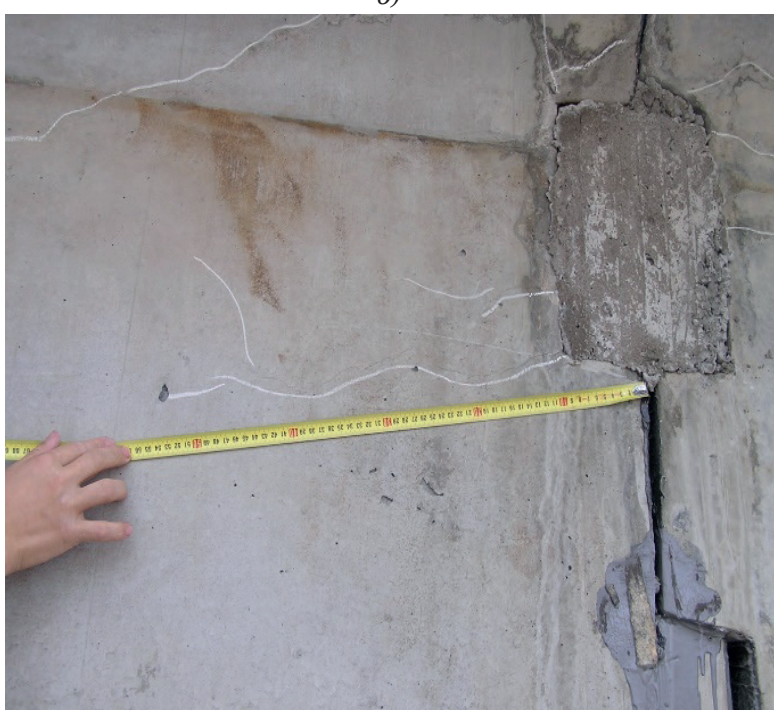

Figure 12 Cracks formation in blocks concrete in the monolithic insert zone after stressing of 42.0 m-long composite beam by tendons: the southern side of No. 1 adhesive joint; b) the northern side of No.1 adhesive joint

Quite strict requirements have been imposed on the formwork shapes regarding the accuracy of its manufacture in accordance with the project requirements. According to the project, the manufacturing tolerances of the end panels of the block formwork should have been such that the exact contact of the joined planes of the combined blocks is ensured and the imperfection of their contact should have been no more than $\pm 1 \mathrm{~mm}$, which is not possible in the manufacture of reinforced concrete structures.

Figure 9 shows the ends of the outer or end and middle segments of the composite beam in No. 1 adhesive joint zone after the tensioning of the tendons. As can be seen from Figure 9, there is a loose contact of the segment joint surfaces as a result of inaccurate manufacturing of the formwork end panels.

At the next stage of work, after the tendon tensioning, the grout was injected into the ducts and then two monolithic dowels were concreted, one of which is shown in Figure 9. The grout has been injected into the ducts through the fittings installed at the end of the end segments (Figure 10).

Longitudinal and inclined cracks have been formed in the concrete of the middle and end segments in No. 1 and No. 2 joints zones during the tendon tensioning due to manufacturing of the blocks' joint surfaces (Figures 11, 12). The cracks formed in the concrete of the middle and extreme blocks during the tensioning of the bundles of prestressed reinforcement revealed the deficiencies of the proposed structural concept of the joint. 


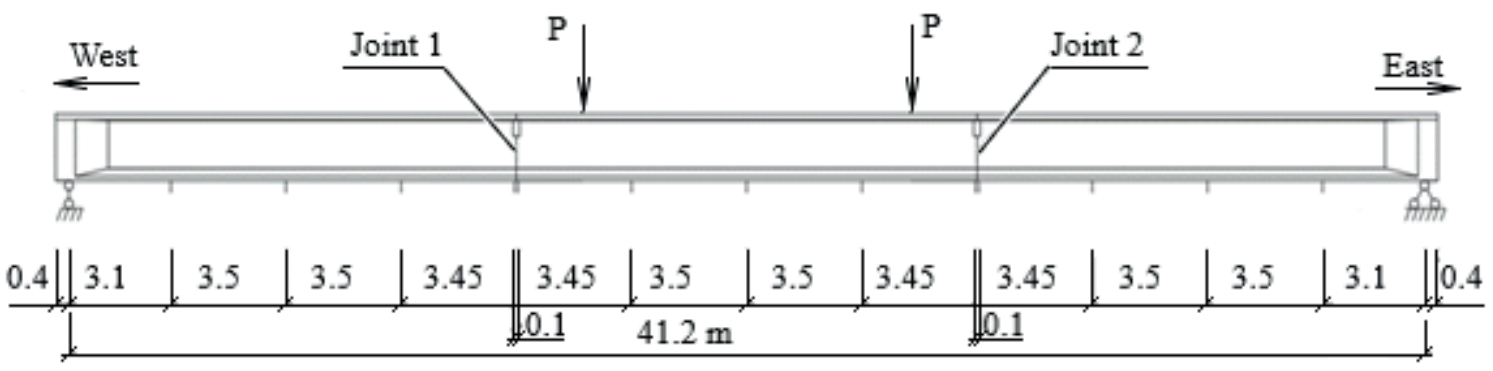

a)

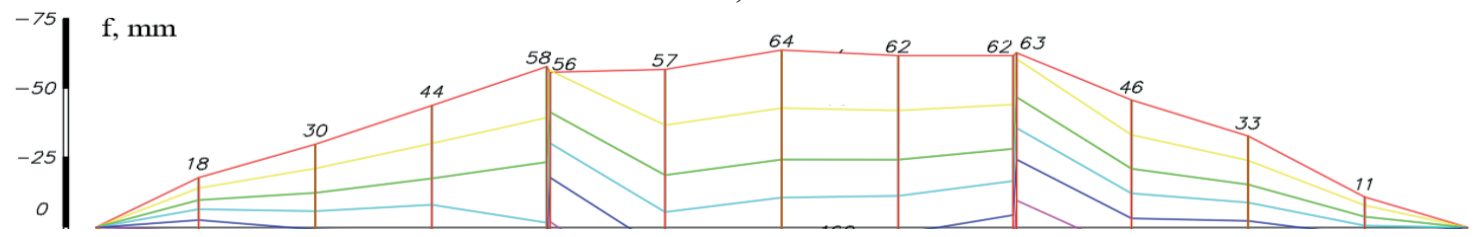

b)

Figure 13 Diagram of camber of $42.0 \mathrm{~m}$-long composite beam (a) and the outline of its bottom surface, including the weight of the loading devices (b)

\section{Result and discussion}

\subsection{Preparation for beam testing}

An instrumental survey of the composite beam bottom has been conducted using the geodetic tools in order to determine camber of the beam. The instrumental survey has been conducted using the C3030 SOKKIA level and a surveying rod, staff.

The experimental hogging in $42.0 \mathrm{~m}$-long composite beam midspan was $69.0 \mathrm{~mm}$ and taking into account the weight of the loading devices $-64.0 \mathrm{~mm}$. The calculated camber in the beam midspan, determined taking into account the increased characteristics of K-7 strands, was $64.5 \mathrm{~mm}$. The difference between the calculated and experimental camber in the beam midspan was $4.5 \mathrm{~mm}$. Figure 13 shows the diagram of the outline of the beam bottom, including the weight of the loading devices. The outline has a shape of a curve close to a parabola [10].

A computational and analytical check was also performed.

Table 1 shows the results of the calculation of the beam bending.

The actual strength of the girder concrete has been determined prior to testing of the beam. The concrete strength has been assessed by the shock pulse monitoring using IPS-MG4.03 electronic concrete strength meter, developed by "SKB Stroypribor" LLC (Chelyabinsk, Russia). The concrete strength has been assessed in accordance with [11] and [12] requirements.

Table 2 shows the processing results of the experimental values of concrete strength.

The experimental concrete strength class in composite beam blocks on the test day according to

Table 1 Calculation results of beam bending

\begin{tabular}{|c|c|c|c|c|}
\hline & Calculation of bending & Designation & Value & Measurement unit \\
\hline 1 & $\begin{array}{l}\text { Girder deflection caused by prestressing } \\
\text { force }\end{array}$ & $1 / \rho_{\text {в }}$ & $6.5710^{-7}$ & $\mathrm{~mm}^{-1}$ \\
\hline 2 & Girder deflection due to the action of self-weight & $\mathrm{f}_{\mathrm{cB}}$ & 74.9 & $\mathrm{~mm}$ \\
\hline 3 & $\begin{array}{l}\text { Calculated beam deflection in the midspan section or } \\
\text { centre }\end{array}$ & $\mathrm{f}_{2}$ & 64.5 & $\mathrm{~mm}$ \\
\hline
\end{tabular}

Table 2 Concrete strength data

\begin{tabular}{ccccccc}
\hline $\begin{array}{c}\text { Structure } \\
\text { name }\end{array}$ & $\begin{array}{c}\text { Number of } \\
\text { experimental } \\
\text { unit values, } \mathrm{n}\end{array}$ & $\begin{array}{c}\text { Average value } \\
\text { of concrete cube } \\
\text { strength } \overline{\mathrm{R}}\end{array}$ & $\begin{array}{c}\text { Standard } \\
\sigma, \\
\mathrm{MPa}\end{array}$ & $\begin{array}{c}\text { Coefficient of } \\
\text { variation, }\end{array}$ & $\begin{array}{c}\text { Student's } \\
\text { coefficient, } \\
\mathrm{t}_{\text {st }}\end{array}$ & $\begin{array}{c}\text { Experimental } \\
\text { concrete class, } \\
\mathrm{B}\end{array}$ \\
\hline $\begin{array}{c}\text { End segment } \\
\text { block No. } 1\end{array}$ & 22 & 57.59 & 8.72 & 0.151 & 1.72 & 42.58 \\
$\begin{array}{c}\text { Middle block } \\
\text { No. } 2\end{array}$ & 22 & 55.03 & 6.67 & 0.126 & 1.72 & 41.56 \\
$\begin{array}{c}\text { Extreme } \\
\text { block No. 3 }\end{array}$ & 22 & 58.35 & 8.13 & 0.139 & 1.72 & 44.37 \\
\hline
\end{tabular}




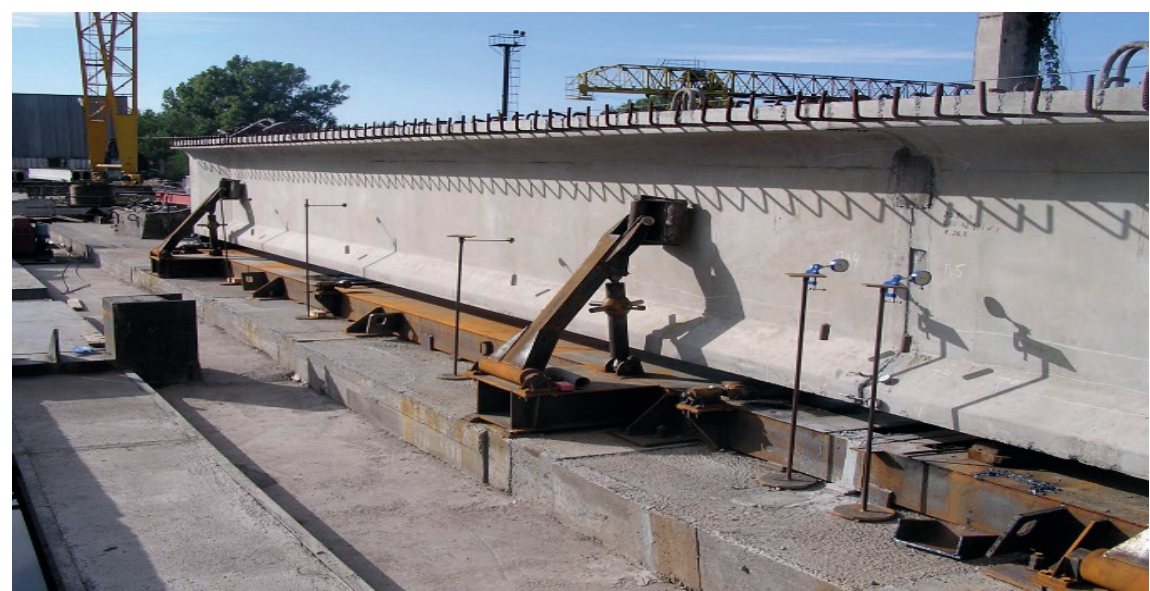

Figure 14 Fragment of a 42.0 m long composite beam with mounted deflectometers and clock type indicators
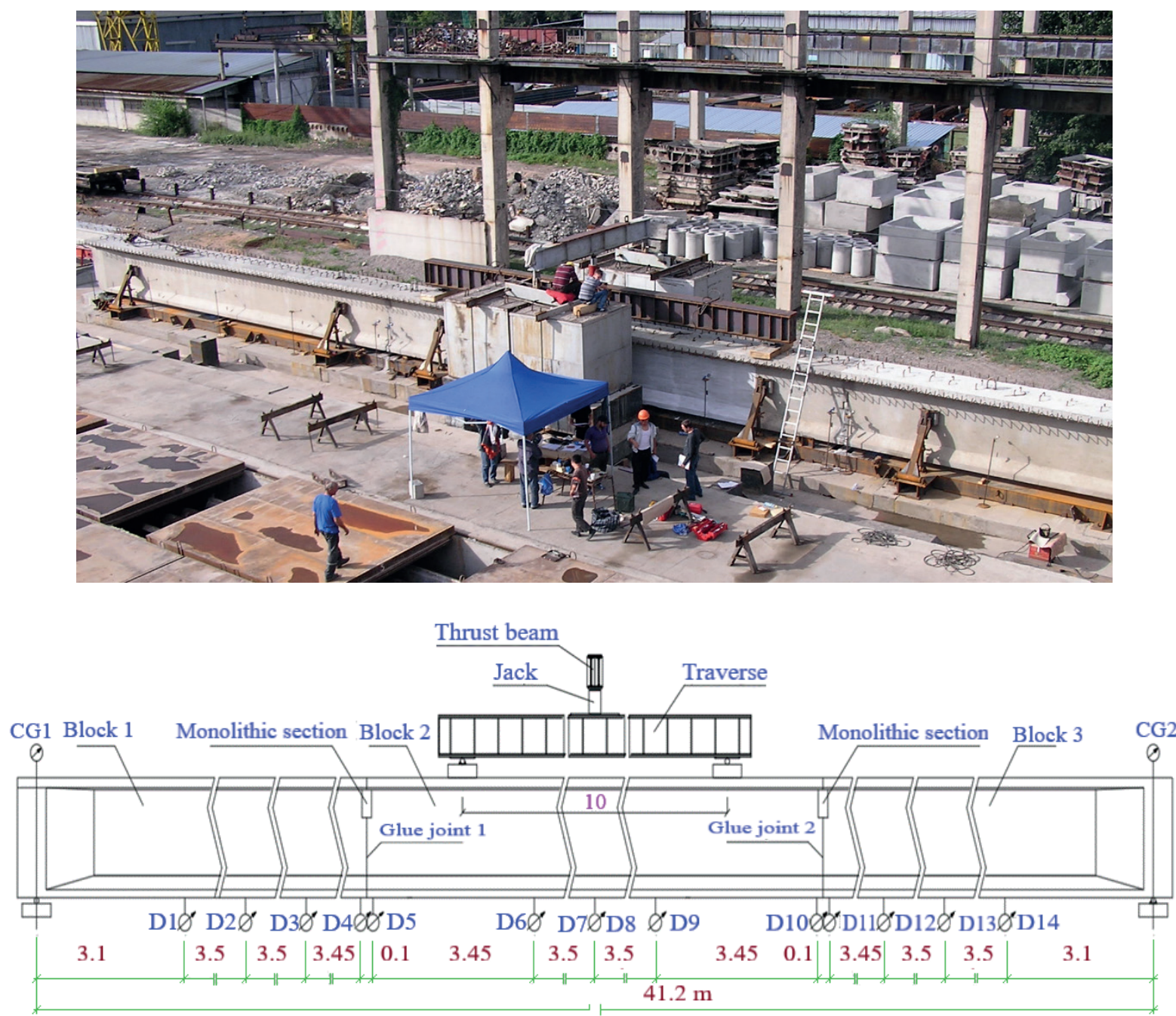

Figure 15 The composite beam scheme with a length of $L=42.0 \mathrm{~m}$ with loading and mechanical devices (CG3, CG3*, CG4 and CG4* indicators in N1 and N2 adhesive joints zones are conditionally not shown): $\varnothing$ - (D1-D4) deflectometers; - (CG1-CG2) mercer clock gauges

the standard classification, corresponds to the nearest smaller class. The compressive strength of the concrete in the extreme blocks corresponded to $\mathrm{C} 40 / 50$ strength class and in the middle block to C55/67 class [13].

\subsection{Beam tests}

The purpose of the tests was to conduct control tests of $42.0 \mathrm{~m}$-long composite beam. It was necessary to 
conduct an experimental verification of the compliance of the actual strength and stress-strain properties of $42.0 \mathrm{~m}$-long composite beam with the design data, according to the test program.

The failure load value during the load test (the ultimate limit states) and deflections values and the width of the cracks under imposed loads during the tests for stiffness and crack resistance (serviceability limit states) are determined according to the test results [14-18].

Figure 14 shows a general view of the $42.0 \mathrm{~m}$ long composite beam in the load bench during the testing.

Control tests of $42.0 \mathrm{~m}$-long composite beam have been carried out according to the scheme provided for in the design documentation before the start of the mass production of these beams.

A power plant which included HJ200P300 hydraulic jack with a lifting capacity of $2000 \mathrm{kN}$, a load cell, highpressure hoses and a manual pumping station have been used to create and control the vertical load value during the beam testing. The Appendix shows the calibration schedule of the hydraulic jack and the pressure gauge.

Figure 15 shows 42.0 m-long composite beam scheme with loading and mechanical devices installed on the experimental structure. The weight of the loading devices was $49.7 \mathrm{kN}$. The estimated length of the prototype adopted in the tests was $41.2 \mathrm{~m}$, i.e. the axes of the supporting parts were located at a distance equal to $0.4 \mathrm{~m}$ from the ends of the end segments of the composite beam. The experimental load on the prototype was transmitted through the traverse beam in the form of two concentrated forces $\mathrm{P}$ in the middle part of the composite beam at a distance of $5.0 \mathrm{~m}$ from its midspan section or centre.

Mercer clock gauges with 0.001 and $0.01 \mathrm{~mm}$ readings have been installed in joints zone to assess the stress-strain state in the No. 1 and No. 2 adhesive joints and the possibility of fixing the opening of joints during loading of the beam (Figure 16). Table 3 presents data on the location of the mercer clock gauges of joints 1 and 2 of the composite beam $\mathrm{L}=42 \mathrm{~m}$.
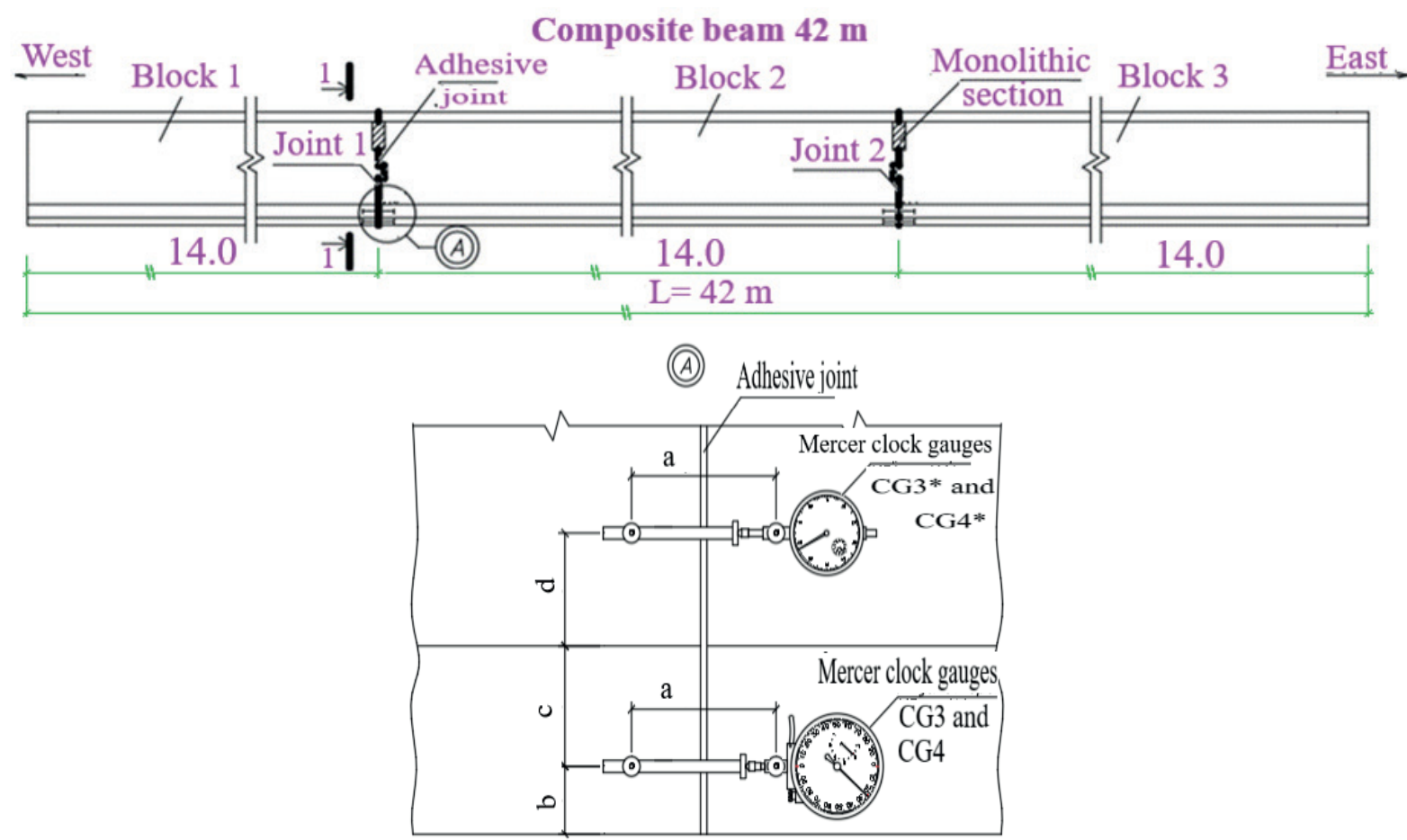

Figure 16 Scheme of dial indicators locations in the joint zones 1 and 2: mercer clock gauges CG3 and CG4 - with a graduation of $0.001 \mathrm{~mm}$; CG3 * and CG4 * with a graduation of $0.001 \mathrm{~mm}$

Table 3 data on the location of the mercer clock gauges of joints 1 and 2 of the composite beam $L=42 \mathrm{~m}$

\begin{tabular}{ccccc} 
Distance & \multicolumn{4}{c}{ Mercer clock gauges base } \\
\cline { 2 - 5 } & CG3*, mm & CG3, mm & CG4*, mm & CG4, mm \\
& 110 & 110 & 110 & 92 \\
$\mathrm{a}$ & - & -45 & - & -70 \\
$\mathrm{~b}$ & - & -80 & - & -55 \\
$\mathrm{c}$ & 75 & - & 30 & - \\
\hline
\end{tabular}


The settlement of supports was controlled using the mercer clock gauges with $0.01 \mathrm{~mm}$ readings.

The category of crack resistance requirements for the composite beam is $-2 \mathrm{~b}$, according to Table $39 *$ [19], which allows crack opening in the beam concrete up to $0.15 \mathrm{~mm}$.

Values of the control loads have been determined when testing the composite beam for strength, crack resistance and stiffness in accordance with the project. The test loads of the girder strength test have subsequently been corrected. In the final form, the control loads when beam testing have been taken as follows:

1. When testing for strength:

- the composite beam strength must be ensured when the load value $2 \mathrm{P}_{\mathrm{k}}=744 \mathrm{kN}$ is reached;

- No. 1 and No. 2 joints strength must be ensured when the load value $2 \mathrm{P}_{\mathrm{K}}=790 \mathrm{kN}$ is reached.

- 2. When testing for the crack resistance:

- there should be no cracks in No. 1 and No. 2 joints when the load value $2 \mathrm{P}_{\mathrm{K}}=536 \mathrm{kN}$ is reached;

- crack widths in the composite beam in the midspan should not exceed the value of $a_{\kappa}=0.15 \mathrm{~mm}$, when the load value of $2 \mathrm{P}_{\mathrm{K}}=534 \mathrm{kN}$ is reached.

3. When testing for stiffness:

- the deflection in the composite beam midspan should not exceed the value equal to $f_{r}=83 \mathrm{~mm}$ when the load value $2 \mathrm{P}_{\mathrm{K}}=436 \mathrm{kN}$ is reached.

The side surfaces of the middle block of the composite beam have been additionally covered with a thin layer of lime to control the moment of the crack formation. The crack width has been determined using a Brinell microscope.

The load has been applied to the composite beam in stages. Readings have been taken from deflectometers and mercer clock gauges after each stage of loading.

\subsection{Test results of 42.0 m-long composite beam}

\subsubsection{Deformability of beam}

The stiffness can be assessed by comparing the actual deflection of the beam under the control load in the beam midspan with the control deflection value in accordance of [20].

The stiffness of the composite beam has been assessed at the first stage of the tests. The experimental deflection of the composite beam in the midspan should not exceed the control deflection value equal to $f_{k}=83$ $\mathrm{mm}$ with a control load of stiffness equal to $2 \mathrm{P}_{\mathrm{K}}=436$ $\mathrm{kN}$. Figure 17 shows the deflection charts in the beam midspan, recorded by $\mathrm{P} 7$ and P8 deflectometers. The experimental deflection in the composite beam midspan had a value equal to $f_{e x p}=62.4 \mathrm{~mm}$, which was $75.2 \%$ of the control deflection when the control load was reached equal to $2 \mathrm{P}_{\mathrm{K}}=436 \mathrm{kN}$.

The prototype beam meets the project requirements, [19] and [20] normative documents in terms of stiffness.

\subsection{Crack resistance of beam}

The crack resistance of No. 1 and No. 2 joints and the crack resistance of the composite beam concrete have been assessed at the second stage of the tests.

Figures 18-22 show deflection charts in 42.0 m-long composite beam, recorded by deflectometers [21].

Cracks should not form in No. 1 and No. 2 joints with a control load of $2 \mathrm{P}_{\mathrm{k}}=536 \mathrm{kN}$ according to the project. Brittle cracking of adhesive composition and, accordingly, opening of No. 1 joint began at an experimental load equal to $2 \mathrm{P}=143.7 \mathrm{kN}$. It should be noted that the cracking process of the epoxy based adhesive composition in No. 1 joint was perceived by ear. Due to the loose connection of the joined end surfaces of the middle and extreme blocks in No. 1 joint, the adhesive had a significant thickness, which was the reason for early crack formation in this joint [22-25].

When considering the charts presented in Figures 18-22 and 23 (CG3 indicator with $0.001 \mathrm{~mm}$ reading), it is clear that, slope of curves occurs at an experimental load of $2 \mathrm{P}=143.7 \mathrm{kN}$, which also indicates the formation of a crack in No. 1 joint. There was a further opening of No. 1 joint during the subsequent loading of the composite beam.

Figure 24 shows opening chart of No. 2 joint during the loading of a composite beam with experimental load. From consideration of this chart it can be seen that opening of No. 2 joint began only with an experimental load of $2 \mathrm{P}=582.7 \mathrm{kN}$, which was recorded by $\mathrm{CG} 4$ mercer clock gauge with $0.001 \mathrm{~mm}$ reading.

The crack resistance of the composite beam concrete has also been evaluated along with the crack resistance assessment of No. 1 and No. 2 joints. The first crack formation in the concrete of the composite beam middle block has been recorded at a load of $2 \mathrm{P}=432.2 \mathrm{kN}$ during the tests. It was speculated that the reason for the early crack formation in the concrete of the composite beam middle block was an imperfection of the structural concept for No. 1 and No. 2 joints [18, 26-27].

Additional cracks have been formed in the concrete of the composite beam during the further loading of the composite beam with an experimental load. The maximum crack opening measured using a Brinell microscope did not exceed the value of $a_{c r}=0.1 \mathrm{~mm}$ at a load of $2 \mathrm{P}=499.7 \mathrm{kN}$.

The crack opening width in No. 1 joint, fixed by the CG3 indicator, located on the composite beam side at a distance of $45 \mathrm{~mm}$ from its lower face, was $a_{c r}=0.7 \mathrm{~mm}$ at a load of $2 \mathrm{P}=527.7 \mathrm{kN}$. And the fixed crack opening width, fixed by $\mathrm{CG} 3 *$ indicator, located on the same side face at a distance of $155 \mathrm{~mm}$ from its lower face was $a_{c r}=0.6 \mathrm{~mm}$.

The fixed crack opening width in No. 2 joint, fixed by the CG4 indicator, located on the side face at a distance of $92 \mathrm{~mm}$ from the lower face of the composite beam, was $a_{c r}=0.003 \mathrm{~mm}$ at a load of $2 \mathrm{P}=582.7 \mathrm{kN}$. 


\subsubsection{Strength of composite beam}

The strength of the composite beam has been monitored at the last, third stage of the tests. The strength of No. 1 and No. 2 joints and the composite beam itself have been assesses during the tests in accordance with the project.

The control load when assessing the strength of the composite beam was $2 \mathrm{P}_{\mathrm{k}}=744 \mathrm{kN}$ and the control load when assessing the strength of No. 1 and No. 2 joints was $2 \mathrm{P}_{\mathrm{K}}=790 \mathrm{kN}$ according to the project.

The failure load of $2 \mathrm{P}_{\text {MAX }}=822.7 \mathrm{kN}$ was achieved during tests which exceeded the control load equal to $2 \mathrm{P}_{\mathrm{k}}=744 \mathrm{kN}$ when checking the strength of the composite beam and the control load equal to $2 \mathrm{P}_{\mathrm{\kappa}}=$ $790 \mathrm{kN}$ when checking the strength of No. 1 and No. 2 joints.

The increase nature in deflection charts in composite beam (Figure 17) and assessment of its stress-strain state testified that it did not achieve the limit state and the pilot design had provisions for the bearing capacity [28].

The possible displacement of the prestressing tendons relative to the composite beam concrete has

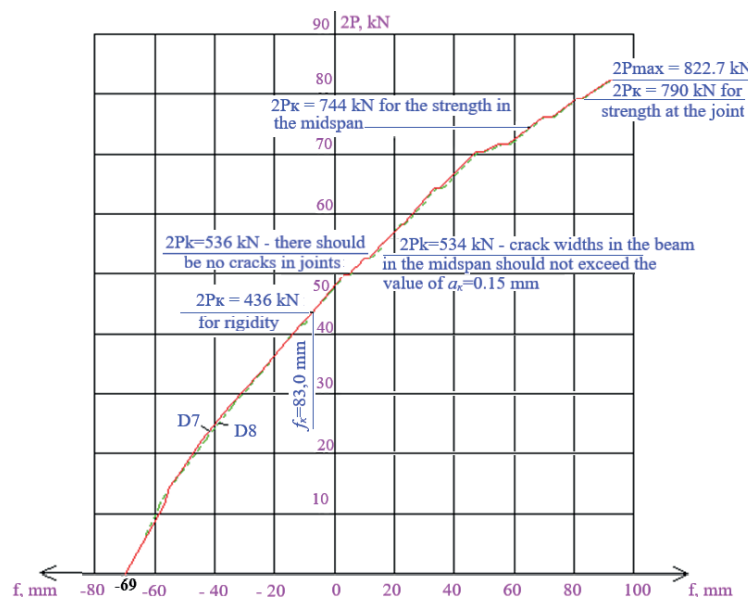

Figure 17 Load-deflection diagram at the section D7 and D8 deflectometers

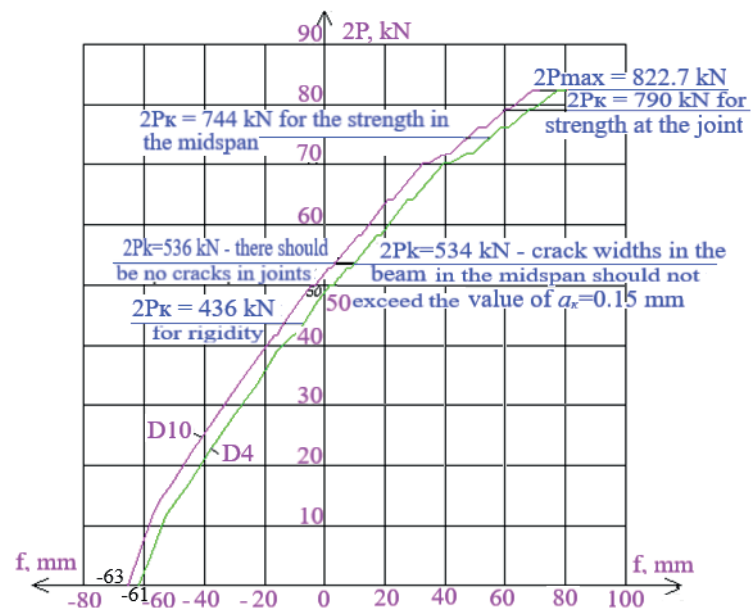

Figure 18 Load-deflection diagram at the section D10 and D4 deflectometers been monitored during the tests. No displacement (pulling) of the bundles of the stressed reinforcement relative to the pilot design concrete has been detected at all the stages of the composite beam loading.

\section{Conclusions}

1. The composite prestressed concrete bridge beam with a length of $42.0 \mathrm{~m}$ is manufactured at "AZMK" (Almaty, Kazakhstan) production base.

2. The control load when checking the composite beam for stiffness is $2 \mathrm{P}_{\mathrm{k}}=436 \mathrm{kN}$. The control deflection of the composite beam should not exceed the value equal to $f_{k}=83.0 \mathrm{~mm}$ at this load. The experimental deflection of the beam in the midspan had a value equal to $f_{\text {exp }}=62.4 \mathrm{~mm}$ at a load of $2 \mathrm{P}_{\mathrm{k}}$ $=436 \mathrm{kN}$, which was $75.2 \%$ of the control deflection value. The composite beam meets the project requirements, [19] and [20] bridge standards in terms of stiffness.

3. The control loads when checking the composite beam joints and concrete for crack resistance had the following values:

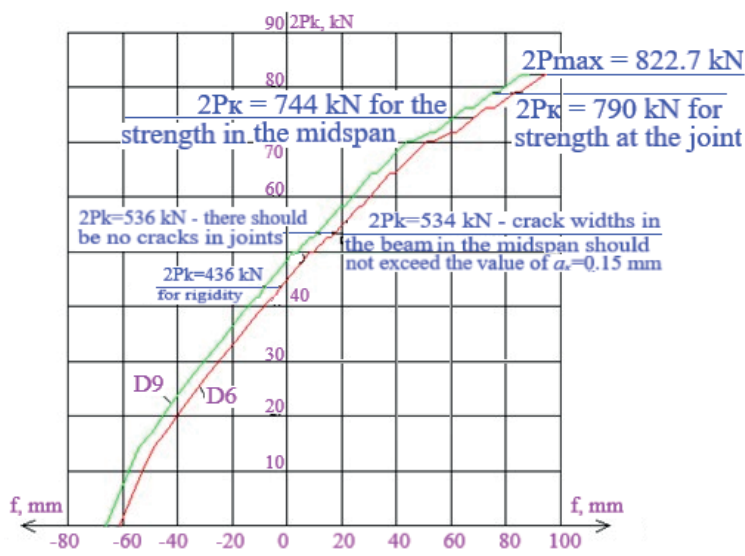

Figure 19 Load-deflection diagram at the section D6 and D9 deflectometers

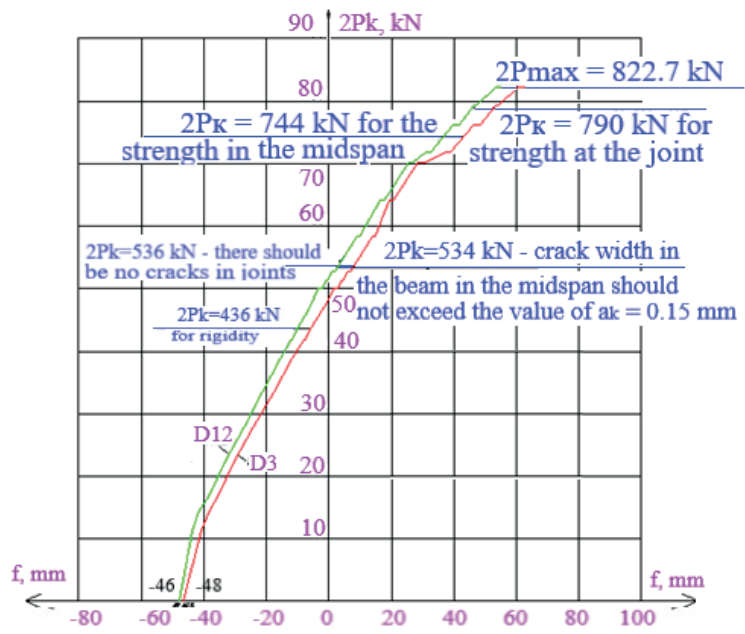

Figure 20 Load-deflection diagram at the section D3 and D12 deflectometers 


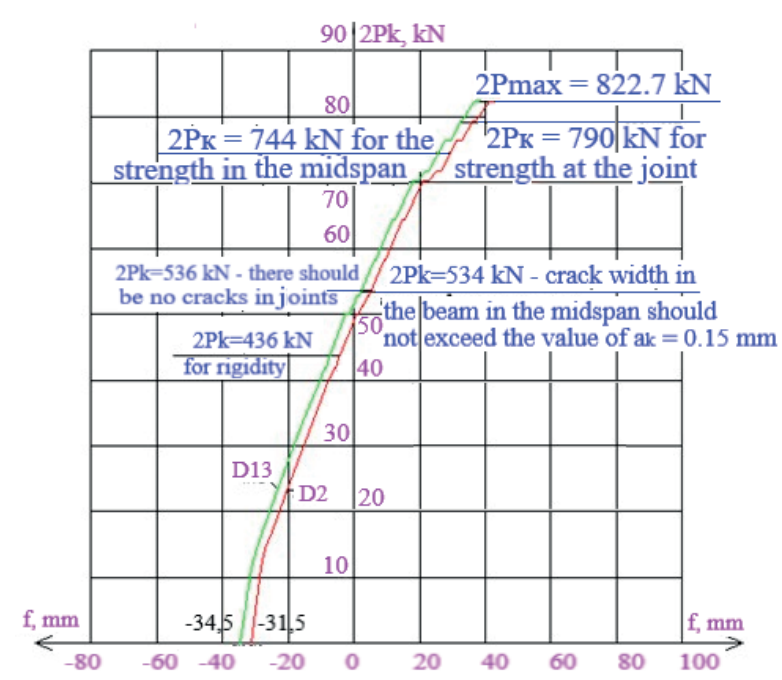

Figure 21 Load-deflection diagram at the section D2 and D13 deflectometers

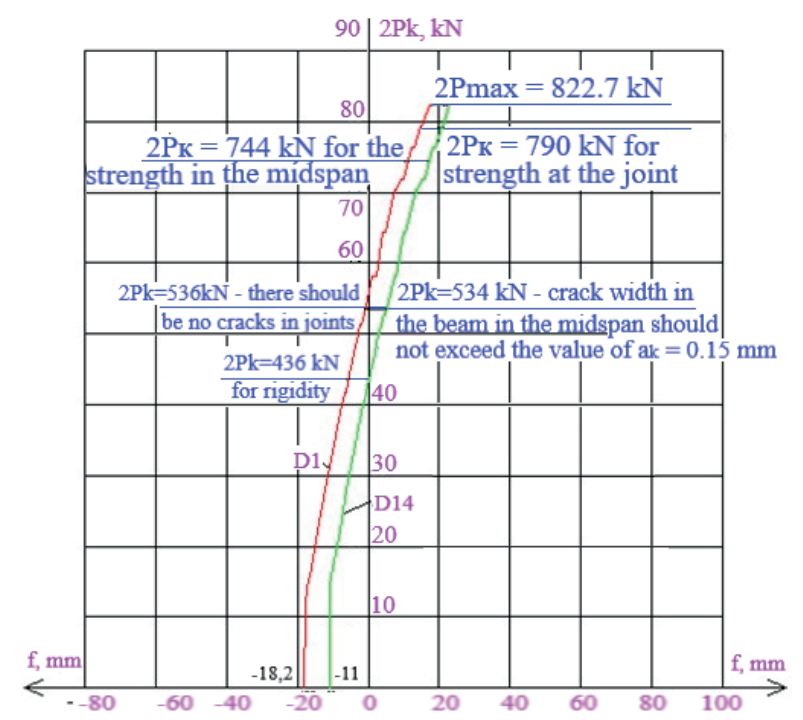

Figure 22 Load-deflection diagram at the section D1 and D14 deflectometers

- cracks should not form in the joints when the load value $2 \mathrm{P}_{\mathrm{k}}=536 \mathrm{kN}$ is reached;

- the crack opening in the composite beam concrete should not exceed the value of $a_{r}=0.15 \mathrm{~mm}$ when the load value $2 \mathrm{P}_{\mathrm{k}}=534 \mathrm{kN}$ is reached.

The early crack formation in No. 1 joint of the pilot design at a load of $2 \mathrm{P}=143.7 \mathrm{kN}$ revealed shortcomings in the structural concept of the composite beam block joints. The results of the control tests when assessing the crack resistance of the prototype showed that the adopted structural concept for the composite beam block joints with the "tooth" and "cutout" was recognized as imperfect.

4. The control loads, when checking the composite

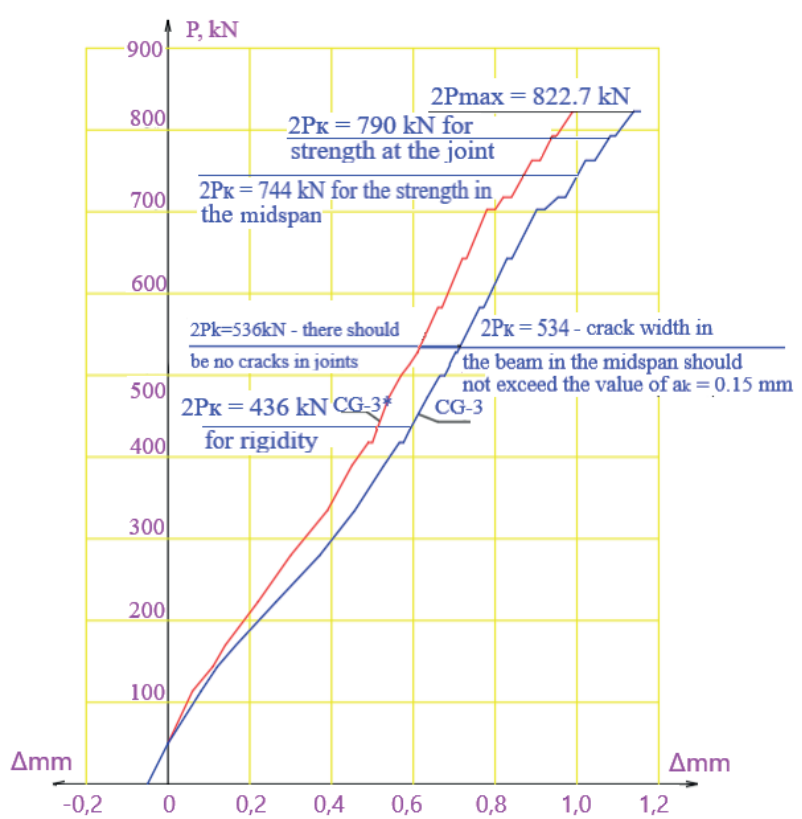

Figure 23 Diagram Force - joint opening in No. 1 joint

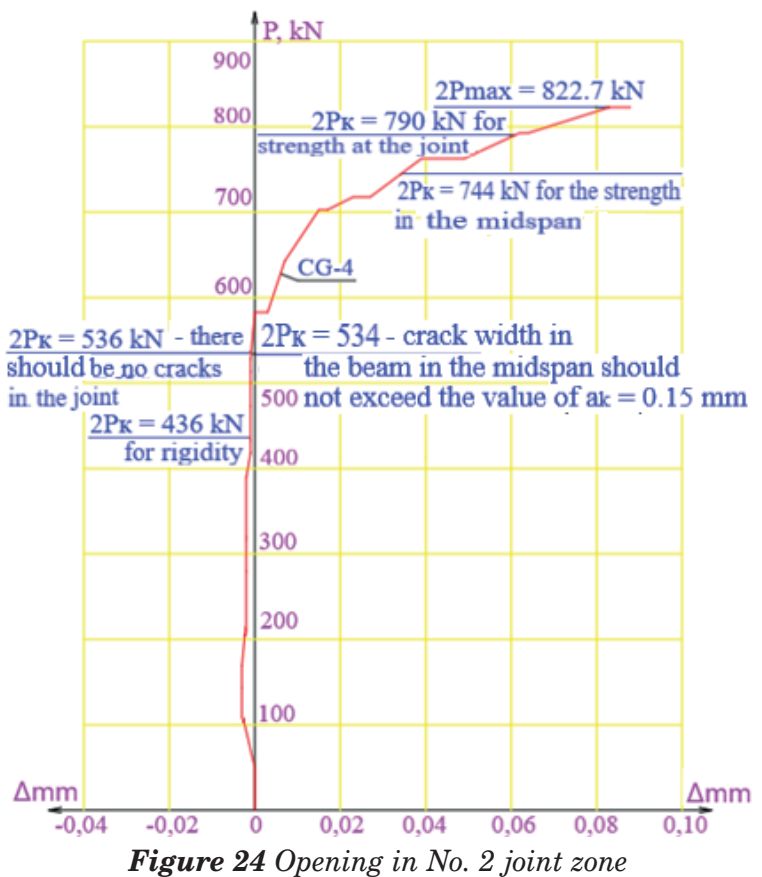

beam for strength, had the following values:

- the composite beam flexural resistance shall be ensured when the load value $2 \mathrm{P}_{\mathrm{k}}=744 \mathrm{kN}$ is reached;

- No. 1 and No. 2 joints flexural resistance be ensured when the load value $2 \mathrm{P}_{\mathrm{k}}=790 \mathrm{kN}$ is reached.

The experimental load of $2 \mathrm{P}_{\mathrm{MAX}}=822.7 \mathrm{kN}$ was achieved during the tests which exceeded the control load equal to $2 \mathrm{P}_{\mathrm{K}}=744 \mathrm{kN}$ when checking the bending capacity of the composite beam and the control load equal to $2 \mathrm{P}_{\mathrm{K}}=790 \mathrm{kN}$ when checking the bending capacity of No. 1 and No. 2 joints.

The composite beam meets the project requirements, [19] and [20] bridge standards in terms of strength. 


\section{References}

[1] GOST 13840-68*. Reinforced steel ropes 1x7. Specifications.

[2] HUGUES, S., SAO, S. K, ALAIN, L. New beam-to-beam joint with concrete embedding for composite bridges: experimental study and finite element modelling. Journal of Constructional Steel Research [online]. 2012, 77, p. 210-222. ISSN 0143-974X. Available from: https://doi.org/10.1016/j.jcsr.2012.05.007

[3] RAJAN, S. Developments in the durability of FRP-concrete bond. Construction and Building Materials [online]. 2015, 78, p. 112-125 [accessed 2014-12-28]. ISSN 0950-0618. Available from: https://doi.org/10.1016/j. conbuildmat.2014.12.106

[4] WEIZHUO, S., BEHROUZ, S., ZHENGUU, L. Longitudinal box-beam bridge joints under monotonic and cyclic loads. Engineering Structures [online]. 2021, 220, 110976 [accessed 2020-06-14]. ISSN 0141-0296. Available from: https://doi.org/10.1016/j.engstruct.2020.110976

[5] AL-BAYATI, R., AL-MAHAIDI, G., KALFAT, R. Torsional strengthening of reinforced concrete beams using different configurations of NSM FRP with epoxy resins and cement-based adhesives. Composite Structures [online]. 2017, 168, p. 569-581 [accessed 2016-12-09]. ISSN 0263-8223. Available from: https://doi.org/10.1016/j. compstruct.2016.12.045

[6] AL-BAYATI, R., AL-MAHAIDI, G., KALFAT, R. Experimental investigation into the use of NSM FRP to increase the torsional resistance of RC beams using epoxy resins and cement-based adhesives. Construction and Building Materials [online]. 2016, 124, p. 1153-1164 [accessed 2016-08-24]. ISSN 0950-0618. Available from: https://doi.org/10.1016/j.conbuildmat.2016.08.095

[7] JOJIBABU, P., ZHANG, Y.X., B. GANGADHARA, P.B. A review of research advances in epoxy-based nanocomposites as adhesive materials. International Journal of Adhesion and Adhesives [online]. 2020, 96, 102454 [accessed 2019-10-12]. ISSN 0143-7496. Available from: https://doi.org/10.1016/j.ijadhadh.2019.102454

[8] KUMAR, P., PATNAIK, A., CHAUDHARY, S. A review on application of structural adhesives in concrete and steel-concrete composite and factors influencing the performance of composite connections. International Journal of Adhesion and Adhesives [online]. 2017, 77, p. 1-14 [accessed 2017-03-21]. ISSN 0143-7496. Available from: https://doi.org/10.1016/j.ijadhadh.2017.03.009

[9] JIANG, C., WAN, B., WU, Y., OMBOKO, J. Epoxy interlocking: a novel approach to enhance FRP-to-concrete bond behavior. Construction and Building Materials [online]. 2018, 193, p. 643-653 [accessed 2018-11-08]. ISSN 0950-0618. Available from: https://doi.org/10.1016/j.conbuildmat.2018.10.183

[10] CAMPILHO, R. D. S .G., BANEA, M. D., NETO, J. A. B. P., DA SILVA, L. F. M. Modelling adhesive joints with cohesive zone models: effect of the cohesive law shape of the adhesive layer. International Journal of Adhesion and Adhesives [online]. 2013, 44, p.48-56 [accessed 2013-02-12]. ISSN 0143-7496. Available from: https://doi.org/10.1016/j.ijadhadh.2013.02.00

[11] GOST 22690-2015. Concretes. Determination of strength by mechanical methods of nondestructive testing.

[12] GOST 18105-86. Concretes. Rules for the strength control.

[13] AZMEE, N. M., SHAFIG, N. Ultra-high performance concrete: from fundamental to applications. Case Studies in Construction Materials [online]. 2018, 9, p. 69-84 [accessed 2018-09-03]. ISSN 2214-5095. Available from: https://doi.org/10.1016/j.cscm.2018.e00197

[14] JURKIEWIEZ B., TOUT, F., FERRIER, E. Push-out and bending tests of steel-concrete adhesively bonded composite elements. Engineering Structures [online]. 2021, 231, p. 327-345 [accessed 2020-12-08]. ISSN 01410296. Available from: https://doi.org/10.1016/j.engstruct.2020.111717

[15] NASSER, A. N., MUAZZAM, G. S., RAMI A. H., JAMAL A. A., KAIS, D. Durability of reinforced concrete beams strengthened by galvanized steel mesh-epoxy systems under harsh environmental conditions. Composite Structures [online]. 2020, 249, p. 569-581 [accessed 2020-05-26]. ISSN 0263-8223. Available from: https://doi.org/10.1016/j.compstruct.2020.112547

[16] ISMAIL, M. I. Q, PAYAM, S., MOHD, Z. J., AZIZ, I. A., ZAINAH, I., UBAGARAM, J. A. The use of wire mesh-epoxy composite for enhancing the flexural performance of concrete beams. Materials and Design [online]. 2014, 60, p. 250-259 [accessed 2014-03-31]. ISSN 0261-3069. Available from: https://doi.org/10.1016/j.matdes.2014.03.075

[17] ISMAIL, M. I. Q, PAYAM, S., MOHD, Z. J. Flexural behaviour of RC beams strengthened with wire meshepoxy composite. Construction and Building Materials [online]. 2015, 79, p. 104-114 [accessed 2015-01-02]. ISSN 0950-0618. Available from: https://doi.org/10.1016/j.conbuildmat.2015.01.013

[18] ASCIONE, F., GRANATA, L., GUADAGNO, L., NADDEO C. Hygrothermal durability of epoxy adhesives used in civil structural applications. Composite Structures [online]. 2021, 265, 113591 [accessed 2021-01-08]. ISSN 0263-8223. Available from: https://doi.org/10.1016/j.compstruct.2021.113591

[19] SNiP 2.05.03-84*. Bridges and pipes.

[20] GOST 8829-94. Reinforced concrete and prefabricated concrete building products. Loading test methods. Assesment of strength, rigidity and crack resistance. 
[21] BOUAZAOUI, L., JURKIEWIEZ, B., DELMAS, Y, LI, A. Static behaviour of a full-scale steel-concrete beam with epoxy-bonding connection. Engineering Structures [online]. 2008, 30, p. 1981-1990 [accessed 2007-12-19]. ISSN 0141-0296. Available from: https://doi.org/10.1016/j.engstruct.2007.12.018

[22] ZHAO, W., YU, Y., XIE, Q. Nonuniform interface failure of steel-concrete composite structures bonded using epoxy resin mortar. Engineering Structures [online]. 2019, 184, p. 447-458 [accessed 2019-01-31]. ISSN 0141-0296. Available from: https://doi.org/10.1016/j.engstruct.2019.01.109

[23] LARBI, A. S., FERRIER, E., JURKIEWIEZ, B., HAMELIN, P. Static behaviour of steel concrete beam connected by bonding. Engineering Structures [online]. 2007, 29(6), p. 1034-1042 [accessed 2006-06-12]. ISSN 0141-0296. Available from: https://doi.org/10.1016/j.engstruct.2006.06.015

[24] JURKIEWIEZ, B., MEAUD, C., MICHEL, L. Non linear behaviour of steel-concrete epoxy bonded composite beams. Journal of Constructional Steel Research [online]. 2011, 67(3), p. 389-397 [accessed 2010-10-04]. ISSN 0143-974X. Available from: https://doi.org/10.1016/j.jcsr.2010.10.002

[25] JURKIEWIEZ, B., MEAUD, C., FERRIER, E. Non-linear models for steel-concrete epoxy-bonded beams. Journal of Constructional Steel Research [online]. 2014, 100, p. 108-121 [accessed 2014-05-08]. ISSN 0143-974X. Available from: https://doi.org/10.1016/j.jcsr.2014.04.005

[26] BUDZIK, M. K., JUMEL, J., BEN SALEM, N., SHANAHAN, M. E. R. Instrumented end notched flexure - crack propagation and process zone monitoring. Part II: Data reduction and experimental. International Journal of Solids and Structures [online]. 2013, 50(2), p. 310-319. ISSN 0020-7683. Available from: https://doi.org/10.1016/j. ijsolstr.2012.08.030

[27] SOUSA, J. M., CORREIA, J. R., CABRAL-FONSECA, S. Durability of an epoxy adhesive used in civil structural applications. Construction and Building Materials [online]. 2018, 161, p. 618-633 [accessed 2017-11-30]. ISSN 0950-0618. Available from: https://doi.org/10.1016/j.conbuildmat.2017.11.168

[28] GAO, N., WANG, P., STEWART, L., ARSON, C. Finite element model of concrete repaired by High Molecular Weight Methacrylate (HMWM). Engineering Structures [online]. 2021, 233, 111860 [accessed 2021-01-03]. ISSN 0141-0296. Available from: https://doi.org/10.1016/j.engstruct.2021.111860 